\title{
The Oriental Passion to Honor the Dead
}

\author{
Ana Ruiz Gutiérrez*
}

\begin{abstract}
To promote the expiation of sins committed on earth, pious donations were common; the chaplaincy was the more common religious foundation, which was intended to secure in perpetuity a number of votes for the eternal repose of the soul of the patron or patrons. To ensure its continued maintenance, material goods were provided; these goods, together with the owner, are generally exhibited in their funerary chapels. Because of the Manila Galleon, which led to the exchange of Asian goods between East and West, it is thus very common to find works from Asia, China, Japan, and the Philippines in the decor of these funerary chapels.
\end{abstract}

KEY WORDS: arts, chaplaincy, China, Manila Galleon, Philippines

\section{PARTICULARITIES OF OBRAS PIAS OF PHILIPPINE ORIGIN}

The consolidation of the Philippine archipelago as a territory under Spanish rule from 1565 to 1898, attached to the Viceroyalty of Nueva España, established a continuing exchange of objects through the famous route of the Manila Galleon, or the Nao de China, which connected the East and West. Along this route, the viceroyalty was key in the distribution of goods; Acapulco was the principal port which connected the Indian route, and from where began the journey which ended in the ports of Seville and Cadiz, Spain, bearing precious works of art from Nueva España and Asia. The Philippines, as a Spanish territory under the protection of Nueva España, attracted Spaniards who occupied positions in public administration, church organizations, or in the consulates of merchants,

"With the assistance of the Office of the Vicerector of Political Science and Research, University of Granada; translated by Concepcion Rosales, Ateneo de Manila University. 
spending long periods in the archipelago, generally until the end of their professional career. ${ }^{1}$

From the start of the Spanish presence in the archipelago, this constant flow of people caused frequent donations of Oriental pieces to Spanish churches, resulting in an exchange of artistic wares through the Manila Galleon, generally composed of objects from China, Japan, and the Philippines. These gifts were not always in the form of goods sent by individuals, but were mostly sent through the foundation of chaplaincies.

The formulation of these donations is very similar to that of the indianos who were in America and, in the same manner, sent substantial quantities of money and works of art to Spain. Thanks to this similarity we can affirm that the mode of transport of said merchandise was similar as well, following a rigorous process that was derived from the Law of the Indies, specifically Title XIV which dealt with the goods of the deceased in the Indies and their administration and accounting in the Casa de la Contratación of Seville. ${ }^{2}$

In reviewing the type of donations, we will concentrate on the chaplaincies, although we will include in the artistic section some gifts of Oriental art willed by individuals.

The term capellania (chaplaincy) is derived from capilla (chapel), a word used to denote three distinct meanings: a place where masses are offered, a burial place with a tomb or epitaph, and a foundation (Lorenzo Pinar 233). As a foundation, it was conspicuously religious and its aim was to secure in a permanent manner, or in perpetuity, a number of votes for the soul/s of the person or persons who were in the care of the founder. Through donations of material goods, the upkeep was provided; due to the permanent character of the foundation, these endowments could not be consumed, and therefore, needed to be invested to ensure an income. The beneficiary of the income was the priest who administered the votes and their number depended on the total of the material endowment and of the

\footnotetext{
${ }^{1}$ The author has written extensively on this in El tráfico artístico entre España y Filipinas (1565-1815).

${ }^{2}$ In Law III, the process is explained thus: “... having received the goods in the Cafa, a published report is made. Within three days, of the receipt of the effects of the deceased en the Casa de Contratación, the Presidente and oficial judges are obliged to explain the reason, indicate the separation of certificates of the deceased, where they died, and their place of origin, and residence, and having identified them, this information is posted on the door of the Casa and a copy on the Puerta del Perdon of the Cathedral, to be known to all." (Recopilación de Leyes de los Reynos de las Indias mandadas imprimir, y publicar por la majestad católica de rey Don Carlos II nuestro señor 205).
} 
rent proportional to the investment (Martínez López-Cano 9-10). These chaplaincies can be divided into two major groups: Colativas (within the Church) and laicales (nonreligious in character). In the former category, the goods belonged to the church that took care of administering them to support the chaplain. Nevertheless, the material possessions that were part of the capellanias laicales remained in the control of the founder, taxed in order to support the religious services stipulated in their constitutions.

The benefits to the founder of the chaplaincy were spiritual, usually the expiation of the sins committed in their lifetime through the pious donations or obras pias, ensuring the eternal salvation of the donor. But this carried with it certain obligations, such as the contribution of sufficient economic resources for its support, and as these were in perpetuity, there was a need to have the proper documentation. For his part, the patrón was obliged to watch over the implementation of the fundamental terms of the contract and verify the celebration of masses in exchange for the social prestige obtained. In return, the chaplain, who received the economic benefit, had to satisfy the spiritual responsibilities established by the founder, including the commitment to reside within the vicinity of the chaplaincy, as an absence of one month would result in his replacement (González Ruiz 475-501). The foundation of chaplaincies was widespread in Spain (and throughout America as well) from the $16^{\text {th }}$ to the $18^{\text {th }}$ centuries, as Gisela von Wobeser describes throughout her book, El Crédito Eclesiástico en la Nueva España.

Obviously the foundation of the chaplaincy was supposed to be able to sustain itself, through a "career of salvation," in the pursuit of acts leading to "a good death." A number of practices were used, consisting of affiliating with a religious confraternity, or with social foundations such as hospitals, colleges, orphanages, and churches, and finally, donations that were mentioned in wills and had to be carried out by the executor of that will of the deceased. Many deceased even specified the circumstances of their funeral; it was common that they be buried in a religious habit and that they select their place of burial-generally, in a convent or church, as near as possible to the main altar (von Wobeser, Vida Eterna 103-05).

With regards to the location of these chaplaincies, the church was one of the preferred places for its establishment, where only a few selected persons could be buried and, in this way, flaunt their social position. As many of these churches were constructed through charitable contributions

${ }^{3}$ For an extensive study of this, one can consult Veronica Zarate Toscano's work, Los Nobles Ante la Muerte en México. 
from the Royal Treasury, the King was the patron, and as such, he was the only one with the right to give the licenses for burial. Thus, the desire to be remembered for eternity in prominent funeral chapels resulted in more funeral applications than the spaces would allow. In Mexico, for example, the civil authorities began to intervene by prohibiting the sale of more land, although this came late. In 1586, the order was given to remove all the remains from the chapels to give way to the king's disposition; however, subsequent decrees failed to mention this resolution. Families who wished to be buried in these privileged spaces sought recourse to the crown through constant correspondence (Pita Moreda 176).

\section{ORIENTAL DONATIONS IN SPANISH CHAPLAINCIES}

From the Philippine archipelago there were numerous donors who established ties with their place of birth through the foundation of chaplaincies. Some notable donors are Manuel Silvestre Pérez del Camino, native of Castañares de Rioja; Tomás García de Cárdenas, native of Higuera la Real in Badajoz; and Juan Manuel Moscoso y Peralta, who was of Peruvian origin, and was named archbishop of Granada, where his beautiful mausoleum is located in the cathedral. Also, a donation mentioned in a will that did not form part of a specific chaplaincy deserves to be mentioned due to the relevance of the contributed pieces, namely the donations of Felipe Iriarte to San Fermín.

Don Manuel Silvestre Pérez del Camino was born on January 8, 1698, in Castañares, Rioja, region of Haro. Even today, he is still considered one of the most distinguished personalities in his hometown. He came from a well-to-do family, being the son of the mayor Custodio Pérez del Camino and of Teresa Vélez de Vergara, and was the fourth of six children. He applied to join the Orden de Santiago (Order of Santiago), and in 1744, he became a member of the order. Although we have no record of the date he boarded a ship to the Indies, we know that at the age of 23 , he worked as an accountant in the Royal Tribunal of Accounts of the provinces of Nueva España, specifically from May 13, 1721 to October 13, 1724. He was treasurer of the Royal Mint from May 13, 1733 to June 16, 1742 (Ruiz Gutiérrez, "Nuevas Aportaciones" 76-87).

His rise to power in Mexico was strengthened when he married into one of the more important families of Nueva España society, the Sanchez de Tagle family. He was married to Doña Josefa Paula de Arguelles y Miranda, great-granddaughter of the first Marquis of Altamira. She was daughter of D. Juan Manuel Arguelles y Miranda, treasurer of the Caja de Pachuca from 
1689, and Ma. Antonia Sanchez de Tagle, who, together with some of her nephews, inherited the fortune of her grandfather, the marquis. ${ }^{4}$

When Peréz del Camino received the title of honorary accountant of the Royal Tribunal of Accounts of Nueva España, an account of his distinguished career was put into writing. This document reveals that, after serving as accountant of the Royal Tribunal of Accounts of the provinces of Nueva España and treasurer of the Royal Mint, he served as Magistrate and Mayor (Archivo General de Indias fojas 4 y 5). He died on October 10, 1766 in Mexico City, at the age of 68. His will was read on December 24 of the same year, stipulating that his estate was left to his widow (Archivo General de la Nación Foja lv).

The construction of an extraordinary chapel filled with ornaments, some of them Oriental, was not only meant to expiate Peréz del Camino's sins, but to also give him and his descendants social prestige. For the parish of his native town of Castañares in Rioja, he made a donation for the construction of a new chapel annexed to the town church (which was built in the $16^{\text {th }}$ century and was considered one of the most spectacular structures in Cuenca del Oja). In 1757, the new chapel was inaugurated and blessed. Peréz del Camino then decided to introduce a chaplaincy of masses for which he appeared before Juan Antonio de Arroyo, royal notary public of Mexico City, to write up a document of incorporation on July 4 of that year (Archivo Parroquial de Castañares de Rioja). The chaplaincy was gifted with 5,300 pesos fuertes (Mexican pesos) which would be used to acquire prime properties. The rent earned from these would then subsidize the costs incurred by the chaplain and the sacristan assigned to care for the chapel and the image of the Virgin of Guadalupe. It would be the obligation of the chaplain to celebrate mass in the chapel every Saturday, as well as during the following holy days: the nine feasts of the Virgin Mary; on December 12, commemorating the apparition of the Virgin of Guadalupe; on March 19, feast of St. Joseph; All Souls Day; the feast of St. Vitores; and, lastly, on the feast of Santo Domingo de la Calzada. His brother Agustin was named the first patrón, as the oldest son and heir to the family estate (Macías and Sanchez 85-108).

At present this chapel has a small, one-piece altar framed by symmetrical pillars and decorated with a painting of St. Michael and the Souls. Together with the images are life-size figures of Christ crucified and of the Sorrowful Virgin, both dressed in clothes from the $17^{\text {th }}$ century. However, the whole area of prominence was once occupied by an altar of two pieces

${ }^{4} C f$. Velázquez, El Marqués de Altamira y las Provincias Internas de Nueva España. 
and three figures, dated to the middle of the $18^{\text {th }}$ century, with the images of Santa Ana, San Joaquín, San José, and a painting on canvas of the Virgin of Guadalupe, signed by Miguel Cabrera. These were part of the donation from Peréz del Camino, together with several gold pieces that were sent to adorn the chapel. At present, only a chalice and a portapaz of the Virgin of Guadalupe remain.

However, the detail of the chapel most relevant to this study are four vaulted niches near the altar. These niches should have been occupied by four of six sculptures, of Hispanic-Filipino origin, that were sent by Peréz del Camino together with the Virgin of Guadalupe. The surviving images are now preserved at the Diocesan Museum of Calahorra. ${ }^{5}$ Based on the size of the niches, we have deduced that originally the images were all 41 $\mathrm{cm}$. tall, and were of the following saints: St. John the Baptist, St. Michael, St. Ferdinand III, and St. Joseph with the Child Jesus (which stood together as one group). Peréz del Camino's will also mentions an image of the Virgin of the Holy Rosary that was too big to be displayed in a niche. ${ }^{6}$

Today, only the statues of St. John the Baptist, St. Ferdinand III, and the Child Jesus are preserved at the museum. The image of St. Joseph was apparently sold by the parish in 1947, together with the images of the Virgin and of St. Michael, owing to their state of deterioration and the little value then attributed to these figures. ${ }^{7}$

Undoubtedly the most exceptional piece of this donation is the sculpture of St. Ferdinand III, the only known example of this iconography in ivory carvings of Hispanic-Filipino origin. The model that the piece of sculpture is based on is a wooden piece that is preserved in the Museum of San Agustin in Manila. However, it has some details that were probably inspired by one of the images of the Spanish monarchs done in that period,

5"[F]or the decoration of the said Chapel, like a silver lamp of the weight and worth of 100 pieces of eight, a cross and four candle holders, also made of silver, a note instructing the celebration of masses using the chalice, paten, cruets, plate, and bell and the words of consecration, and six effigies of the saints made of ivory that, together with the canvas had also been sent from Ntra. Señora de Guadalupe showing the four apparitions painted very finely." Archivo Parroquial de Castañares de Rioja. Escritura de fundación de 1760. Papeles sueltos, doc. №17. Libro de Fábrica de 1746-1801, f.85r. (Sánchez Trujillano, El arte hispanofilipino 58).

"Ittem una imagen de Nuestra Señora del Rosario de Marfil de tres quarttas en treintta Pessos" (Archivo General de la Nacion Foja 19 r).

${ }^{7}$ Because these were made of "colonial ivory, poorly made in México in the mid-18 th century," as stated in the Archivo Parroquial de Castañares de Rioja, in a draft letter written by the parish priest at the back of a funeral certificate dated May 12, 1947 (Sánchez Trujillano, "Los envios de Indias" 255-274). 
as the image is cloaked and has a sword, but without the characteristic globe that accompanied St. Ferdinand III after his canonization.

St. Ferdinand III (fig.1) is shown adorned with a ruff, a suit of armor, breeches above the knee, and high boots with cuffed tops. As royal symbols, he wears the Golden Fleece, a long cloak with a cape adorned with tassels, a crown, and a sceptre of silver. Apparently, the globe in his left hand used as a symbol of universal power is still missing as the Muslim conquest was still ongoing. He has an inscrutable pose, only altered by his arms, flexed at the elbow, and the left leg, positioned slightly ahead of the right leg.

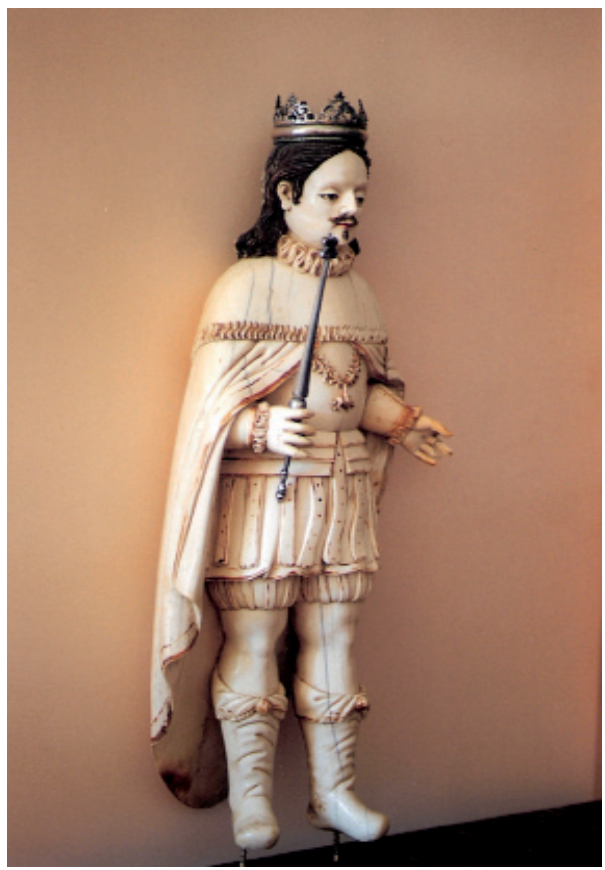

Fig. 1. Image of St. Fernando III; Hispanic-Filipino; ca. $18^{\text {th }}$ Century; Museum of the Diocese of Calahorra, La Rioja, Spain.

The most unique trait of this sculpture is the face, which possesses the principal characteristics of the Hispanic-Filipino ivory carvings. The wide forehead, with the hair combed away from it, eyes slanted with wider upper eyelids, long earlobes, and double chin are all of Asian influence. This contrasts with the fine nose, elegant moustache, 
and goatee. The polychromy is preserved well, above all, in the hair, eyes, and mouth, even in some golden decorations in the attire (Estella Marcos 283-84).

In the town of Higuera la Real, Badajoz, another group of sculptures of ivory sent from the Philippines is preserved. The General of the Royal Galleys of the Philippines, Don Tomás García de Cárdenas, founded three chaplaincies for the Parish Church of Santa Catalina, which are identified in his letters. In those letters, he comments on the shipment in 1670 of several ivory pieces: a Virgin and Child, a boy who is the Redeemer of the World, with the head and hands made of ivory, and with His own wardrobe, which actually is still preserved in the said parish (Solis Rodríguez 93).

In Granada, in the chapel of San Miguel in the Cathedral, a mausoleum in honor of Juan Manuel Moscoso Peralta is located. Although originally from Perú, he was archbishop of Granada between 1789 and 1811, under the patronage of King Charles IV. ${ }^{8}$ His whole life is narrated in a tombstone in Latin below his sepulchre, but the most remarkable quality of Moscoso was, undoubtedly, his passion for art, and in particular, his passion for Oriental art. This is proven by his collection of Chinese and Japanese porcelain, begun during his stay in Arequipa, Cuzco, on exhibit in some rooms of the Palace of Viznar, in Granada, where he lived his final days. This palace came to be known as the Cuzco palace, where he surrounded himself with the luxuries of Asia, as proven by the inventory of the treasures of the Viznar Palace made after his death. This mentioned a big collection of Chinese pieces in the principal hall. Some of these pieces were donated by him to his secretary Vicente Martinez Terroba; however, when the funeral chapel was finished, some magnificent Chinese jars from this legacy were used to decorate it, reminding us of his taste for the Oriental up to his death (Gómez Román 133-70; Guillén Marcos 450-53; Alonso Hernández 1147-233).

The pair of jars in question, approximately $1.42 \mathrm{~m}$. in height, are well preserved and flank the two sides of Moscoso's mausoleum (fig.2). They probably date to the Qienlong period (1736-95), of the Qing dynasty (1644-1912) (García-Ormaechea 225-39; Cervera). These were probably made in the factories of Canton for export, as the decoration is exposed symmetrically, above all in the shoulders and the lid, and as such, related to the familia rosa pattern, ${ }^{9}$ named after the predominance of the rose color

${ }^{8}$ I am grateful for the collaboration of Ana María Gómez Román and Francisco Valiñas López in this section.

${ }^{9}$ Denominación utilizada en Occidente a partir de la obra del francés Albert Jacquemart. Histoire de la cerámique chinoise. París. 1862. 
tone. The floral decoration is dominant, with peonies and cherry blossoms; several geometric elements border the shoulders and neck. Both jars are complete with their original lids with winged sides and the handles in the form of lions. ${ }^{10}$

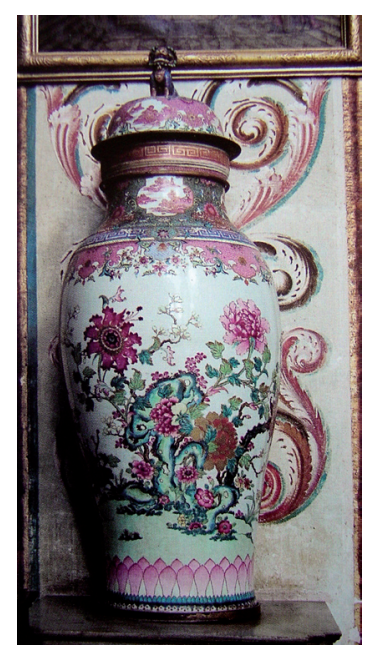

Fig. 2. Porcelain jar; Chinese; ca. $18^{\text {th }}$ Century; Capilla de San Miguel, Cathedral of Granada, Spain.

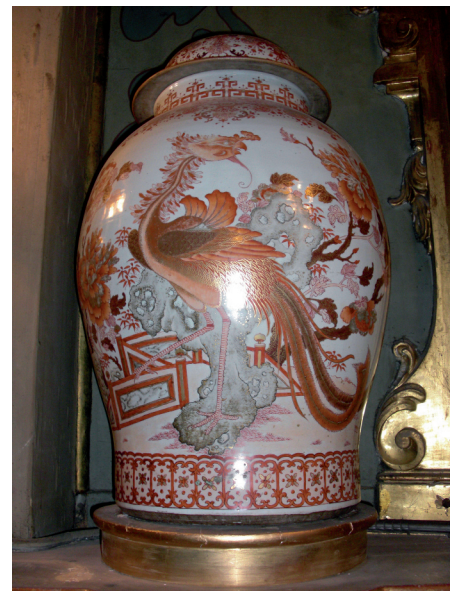

Fig. 3. Porcelain jar; Chinese; ca. $18^{\text {th }}$ Century; Church of San Saturnino, Pamplona, Spain.

The donation of Chinese jars to chapels is not exclusive to Granada; we find numerous examples throughout Spain, of which the collection of Felipe Iriarte, native of Alcoz, Valle de Ulzama, Navarra, can be singled out, although this would not be the only gift he would give to his hometown, as we will see later. ${ }^{11}$ The pair of jars were sent in 1768 , probably from Mexico where he resided, to the chapel of Nuestra Señora del Camino in the church of San Saturnino in Pamplona, where the Virgen del Camino

10"Siddharta Gautama, the historic Buddha, was an Indian prince of the Shakya clan, whose dynastic emblem was the lion. From the sixth century BC, the lion was the principal symbol of Buddha, followed by the anthropomorphous image of the Buddhist cult. Fo means Buddha in China, where in time the Buddhist lion became the guardian of the Buddhist temples and afterwards, was integrated in the popular iconography as protector of the chinese family.” Artigrama. nำ18, (2003), pp. 231-52.

${ }^{11}$ I am grateful to Luis Turiel, Mercedes Orbe, and Juana Leceaga, for their generosity in offering the necessary information and images from Pamplona. 
is watched over in her private niche (Molins Mugueta and Fernández Gracia 63-117).

These jars (fig. 3) were fabricated probably in the Qienlong period (1736-1795) of the Qing dynasty (1644-1912) of the red iron typology, so named because of the predominant use of this color. We note the symmetry of the flowers on the shoulders, the double-border edging with intertwining flowers and leaves, allowing one to see the transparent porcelain base. The central element is the feng-huang or the phoenix, so characteristic of the Chinese iconography, symbol of opulence and beauty, one leg leaning on a rock, fascinating us with his attractive plumage, a range of reddish hues from orange to maroon. Behind a panel (or screen) is a scene of many flowers, among which are big peonies and cherry blossoms.

However, this donation is only a preview of one of the most important artistic ensembles of Asian origin that are found in Spain. By this, we refer to Iriarte's donation of the mitre and the staff of St. Fermin in 1776 from Mexico. These were entrusted to the town hall through a resident of Pamplona, Da. Ma. Fermina Ciriza (Purroy y Turrillas 141-47; Molins Mugueta).

On February 19, 1776, the city council of Pamplona met in session to note the receipt of "a rich silver gilt mitre with a staff, adorned with flowers in filigree and a variety of precious stones, butterflies in flight and small golden scorpions of rare beauty for our glorious patron saint, San Fermin" (Archivo Municipal de Pamplona Fol. 235r-236v).

Through the contents of the letter, the transcription of which is found in the corresponding minutes preserved in the municipal archive, it is known that the mitre and staff arrived in Cadiz on the ship El Aquiles, in a covered case definitely prepared by Iriarte himself. What is even more interesting is that its Oriental origin is indicated: ". . . from the Philippines they brought this in a bad state in a big box that fitted two cases, the reason why it came in a bad condition and I don't even know why it was not totally destroyed . .. which positive proof is the sea voyage from Manila (from Canton by sea) and fortunately until Acapulco" (Archivo Municipal de Pamplona). Lastly, Iriarte mentions in his letter that the donation, upon arrival in Cadiz, must be sent to Pamplona by ship from San Sebastian: "taking into account the difficulties of bringing in that kingdom (Navarre) silver objects and could be delayed in Logroño" (Archivo Municipal de Pamplona).

After crossing the Pacific, when the consignment arrived from the Far East to the Mexican port of Acapulco, there were several setbacks. The carrier hid it, it was not registered (perhaps for fiscal reasons), and consequently, the mitre and staff were confiscated and surrendered to the judge. When the judge ordered its return there were indications that the 
consignment had been tampered with. There were missing "butterflies and scorpions that served as templates," which made Iriarte decide "to ask for them in the coming year, and also, other pieces which I noticed were missing, especially, the cross which was not included, as should have been part of the corresponding consignment" (Archivo Municipal de Pamplona). The templates alluded to were part of the decoration, the flowers, butterflies, etc. that were superimposed on the plates through small metal coils: this feature offered the possibility of stretching the pieces to lessen the bulk of the decoration.

With the arrival of the magnificent gift, the municipal council wrote a highly complimentary letter on March 8, 1766, filled with praises directed to Iriate, with 24 engraved indulgences of San Fermin, half of these blessed by the Bishop, and one dozen booklets with the novena of the saint. At the same time, the flaws were noted, and an expert silversmith from Pamplona, José Jiraud, was assigned to do a thorough description of the flaws. Jiraud sent his report on February 22.

The mitre (fig.4) is composed of 12 sheets of gilt silver, supported on the sides and secured, with a carving of intertwined flowers. Lacelike forms or small holes fill up the plain spaces to secure the superimposed filigree pieces. In the front and back, the lower part is adorned with small filigree flowers that are used to mount the stones, some blue, some red. The two hangings (ribbons that hang from behind the mitre) were made of four pieces of filigree with hinges. These are adorned with leaves alternating with 15 margatas and nine butterflies.
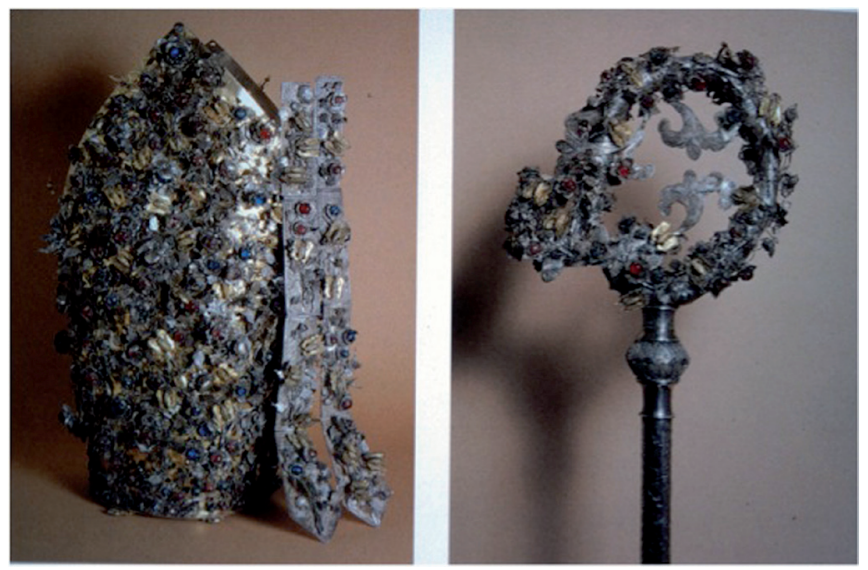

Fig. 4. Mitre and staff of San Fermín; ca. $18^{\text {th }}$ Century; Church of San Lorenzo, Pamplona, Spain. 
The staff sent by Iriarte consisted of five pieces, four for the body, and one more for the tip. All came with screws, numbered to facilitate assembly. The body, made of silver sheets, has slightly embossed pieces, emulating flowers. The neck, in the shape of a hatchet, is decorated with filigree. The major ornament is reserved for the tip, which is formed of two welded halves. Its original decoration consisted of 46 flowers (26 with red stones and 21 blue stones) as well as sculptured leaves and 22 golden butterflies.

Finally, on April 21, 1766, the pieces were submitted to the Obrería de San Lorenzo, in a case appropriate for its contents, the interior covered in crimson velvet, and the outside in leather. On the $26^{\text {th }}$ of the month, which fell on a Saturday, a solemn thanksgiving mass was celebrated together with a Te Deum to commemorate Iriarte's donation.

\section{WORKS CITED}

Alonso Hernández, E. Javier. "Capillas y altares perimetrales." El libro de la catedral de Granada. Ed. Lazaro Gila Medina. Vol. II. Granada: Arzobispado, 2005. 1147-233. Print.

Archivo General de Indias. Indiferente 152.1. Méritos de Manuel Silvestre Pérez del Camino, 22-05-1749, folios 4 and 5. Print.

Archivo General de la Nación. Tierras. Vol. 895. Folio lv. Print.

Archivo Parroquial de Castañares de Rioja. Papeles sueltos no.76. Year 1754. Fol. s/n. Print.

Cervera, Isabel. Arte y Cultura en China. Conceptos materiales y términos de la A a la Z. Barcelona: Serval, 1997. Print.

Clunas, Craig. Chinese Export Art and Design. Kent: Victoria and Albert Museum, 1987. Print.

Díaz Trechuelo, Lourdes. Filipinas: La Gran Desconocida (1565-1898). Navarra: Eunsa, 2001. Print.

Estella Marcos, Margarita. La Escultura Barroca de Marfil en España. Las Escuelas Europeas y Coloniales. 2 vols. Madrid: Consejo Superior de Investigaciones Científicas, Instituto Diego Velázquez, 1984. Print.

García-Ormaechea, Carmen. "La porcelana del Palacio Real." Oriente en Palacio: Tesoros Asiáticos en las Colecciones Reales Españolas. Madrid: Patrimonio Nacional, 2003. 225-39. Print.

---. "El Coleccionismo de Arte Extremo Oriental en España: Porcelana China." Artigrama. No. 18 (2003): 231-52. Print.

Guillén Marcos, Esperanza. "Las capillas del Clasicismo Ilustrado en la Catedral de Granada." La Catedral de Granada: La Capilla Real y la Iglesia del Sagrario. Vol. I. Granada: Cabildo de la S.I. Catedral Metropolitana de Granada/Caja Sur, 2007. 450-53. Print. 
Asian Perspectives in the Arts and Humanities 3.1 (2013): 123-136

Gómez Román, Ana María. "Promoción Artística y Coleccionismo Episcopal Entre Andalucía y América." Andalucía en América: Arte y Patrimonio. Ed. Rafael López Guzmán. Granada: Atrio/Universidad de Granada, 2012. 133-70. Print.

González Ruiz, Manuel. "Las Capellanías Españolas en su Perspectiva Histórica." Revista Española de Derecho Canónico. No.14 (1950): 475-501. Print.

Lorenzo Pinar, Francisco Javier. Muerte y Ritual en la Edad Moderna: El Caso de Zamora, 1500-1800. Salamanca: Universidad de Salamanca, 1991. Print.

Macías, Rafael and José María Sánchez. "El Patronato Artístico de Manuel Silvestre Pérez del Camino en la Rioja." Atrio. No. 15-16 (2009-2010): 85-108. Print.

Martínez López-Cano, Pilar. "El costo de una pronta salvación en Nueva España, siglos XVI-XVII." Universidad de Santiago de Chile. Colloquium on "El Costo de Una Pronta Salvación: Nueva España y Chile." 4-5 March 2003. Web.

Molins Mugueta, José Luis and Ricardo Fernández Gracia. "La capilla de Nuestra Señora del Camino." La Virgen del Camino de Pamplona. IV Centenario de su Aparición (1487-1997). Pamplona: Mutua de Pamplona, 1987. 63-117. Print.

Molins Mugueta, José Luis. Capilla de San Fermín en la Iglesia de San Lorenzo de Pamplona. Pamplona: D.F.N.-Ayuntamiento de Pamplona, 1974. Print.

---. "La Mitra y Báculo Dieciochescos de San Fermín." Publicado en Diario de Navarra, no extraordinario de San Fermín. 7 July 1984. 9-10. Print.

Pita Moreda, Ma. Teresa. Los Predicadores Novohispanos del Siglo XVI. Salamanca: Editorial San Sebastián, 1992. Print.

Purroy y Turrillas, Carmen. "Donaciones procedentes de América y de Filipinas en Navarra." Homenaje a Lourdes Díaz Trechuelo. Córdoba: Publicaciones del Monte de Piedad y Caja de Ahorros de Córdoba, 1991. 141-47. Print.

Recopilación de Leyes de los Reynos de las Indias mandadas imprimir, y publicar por la majestad católica de rey Don Carlos II nuestro señor. Tomo V, reproducción facsímil de la edición de Julián de Paredes de 1681, Madrid, Ediciones de Cultura Hispánica, 1973.

Ruiz Gutiérrez, Ana. El Tráfico Artístico Entre España y Filipinas (1565-1815). Granada: Universidad de Granada, 2005. Recurso Electrónico.

---. "Nuevas Aportaciones Sobre la Donación de D. Manuel Silvestre Pérez del Camino a Castañares de Rioja." Revista Digital del Seminario de Escultura. No.2 (2009): 76-87. Print.

Solís Rodríguez, Carmelo. "Legado Artístico de Filipinas." Platería Hispanoamericana: Siglos XVI-XIX. Badajoz: Secretariado Diocesano del Patrimonio Históricoartístico, 1984. 92-96. Print.

Sánchez Trujillano, Ma Teresa. El Arte Hispanofilipino en la Rioja: Los Marfiles. Logroño: Museo de La Rioja, 1998. Print.

---. "Los Envíos de Indias: El Arte Colonial en la Rioja." Anales del Museo de América. No. 9 (2001): 255-74. Print.

Velázquez, Ma del Carmen. El Marqués de Altamira y las Provincias Internas de Nueva España. México: El Colegio de México, 1976. Print. 
von Wobeser, Gisela. El Crédito Eclesiástico en la Nueva España: Siglo XVIII. México: UNAM. Instituto de Investigaciones Históricas, 1994. Print.

---. Vida Eterna y Preocupaciones Terrenales. Las Capellanías de Misas en la Nueva España, 1600-1821. México: Universidad Nacional Autónoma de México, 2005. Print.

Zarate Toscano, Verónica. Los Nobles Ante la Muerte en México: Actitudes, Ceremonias y Memoria (1750-1850). México: El Colegio de México/Instituto Mora, 2000. Print.

Zóbel De Ayala, Fernando. Philippine Religious Imagery. Manila: Ateneo UP, 1963. Print.

Ana Ruiz Gutiérrez is a research associate at the Department of Art History, University of Granada, Spain. She obtained her PhD in Art History from the same university and graduated Summa Cum Laude. Her dissertation, "Artistic Traffic between Spain and the Philippines (15651815)," focused on the artistic links between the Philippines and Spain through the cultural exchange facilitated by the trans-Pacific route of the Manila Galleon. Her research assessed the importance of the Viceroyalty of New Spain to the survival of the Philippine archipelago as the farthest territory of the Spanish metropolis until the $19^{\text {th }}$ century. 